\title{
Pengaruh Free cash flow, Kepemilikan Institusional, Profitabilitas dan Leverage Tehadap Kebijakan Dividen Tunai Pada Perusahaan Property dan Real estate yang Terdaftar di Bursa Efek Indonesia
}

\author{
Syelly Wulandari*, Nita Priska Ambarita **, Mia Dwi Puji Wahyuni Darsono*** \\ "Magister manajemen, Universitas Mulawarman, syellywd@gmail.com \\ ${ }^{* *}$ Magister manajemen, Universitas Mulawarman, nitaambarita82@gmail.com \\ *** Magister manajemen, Universitas Mulawarman,mia.dwipuji@gmail.com
}

\section{Article history:}

\section{Article history:}

Received 20 Maret 2019

Received in Revised 15 Agustus 2019

Accepted 20 November 2019

\section{Keywords:}

Cash Flow, Institutional Ownership,

Profitability, Leverage.

\begin{abstract}
A B S T R A C T
This research aims to examine and analyze the effect of free cash flow, institutional ownership, profitability and Leverage on dividend policy by using an approach multiple regression model. The proxies used to measure the financial elements are free cash flow, institutional ownership, Return on Assets and debt to equity ratio. The population in this research is property and real estate companies listed in Indonesia Stock Exchange for six years (2014-2019). Election sample procedure uses purposive sampling and the result are existed 5 companies that fulfill criteria so that amount of data studied by 30 data. The results of this research show that free cash flow, institutional ownership and profitability have a significant effect on dividend policy proxied by Dividend payout ratio. Leverage which is measured by debt to equity ratio hasn't a significant effect on dividend policy. Free cash flow has a positive effect on dividend policy. Institutional ownership has a positive effect on dividend policy. Profitability which is measured by Return on Assets has a negative effect on dividend policy. The predictive ability of these variabel on dividend policy is 49,6\% as shown by the amount of $R$ square, while $50,4 \%$ is affected by the other factor which is not included in the research model.
\end{abstract}

Penelitian ini bertujuan untuk menguji dan menganalisis pengaruh arus kas bebas, kepemilikan institusional, profitabilitas dan Leverage pada kebijakan dividen dengan menggunakan pendekatan model regresi berganda. Proxy yang digunakan untuk mengukur unsur-unsur keuangan adalah arus kas bebas, kepemilikan institusional, pengembalian aset dan rasio utang terhadap ekuitas. Populasi dalam penelitian ini adalah perusahaan properti dan real estate yang terdaftar di Bursa Efek Indonesia selama enam tahun (2014-2019). Prosedur pemilihan sampel menggunakan purposive sampling dan hasilnya ada 5 perusahaan yang memenuhi kriteria sehingga jumlah data yang diteliti sebanyak 30 data. Hasil penelitian ini menunjukkan bahwa arus kas bebas, kepemilikan institusional, dan profitabilitas memiliki pengaruh yang signifikan terhadap kebijakan dividen yang diproksi dengan rasio pembayaran dividen. Leverage yang diukur dengan rasio hutang terhadap ekuitas tidak berpengaruh signifikan terhadap kebijakan dividen. Arus kas bebas memiliki efek positif pada kebijakan dividen. Kepemilikan institusional berpengaruh positif terhadap kebijakan dividen. Profitabilitas yang diukur dengan pengembalian aset memiliki efek negatif pada kebijakan dividen. Kemampuan prediktif variabel-variabel ini pada kebijakan dividen adalah 49,6\% seperti yang ditunjukkan oleh jumlah R square, sedangkan 50,4\% dipengaruhi oleh faktor lain yang tidak termasuk dalam model penelitian.

AKUISISI : Jurnal Akuntansi

Website : http://www.fe.ummetro.ac.id/ejournal/index.php/JA

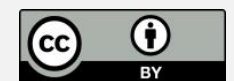

This is an open access article distributed under the terms of the Creative Commons Attribution 4.0 International License, which permits unrestricted use, distribution, and reproduction in any medium, provided the original work is properly cited.

E-mail address: syellywd@gmail.com

Peer review under responsibility of Akuisisi : Accounting Journal. 2477-2984. http://dx.doi.org/10.24217 


\section{PENDAHULUAN}

Dividen merupakan salah satu bentuk peningkatan kemakmuran bagi pemegang saham. Dividen yang dibagikan secara tunai umumnya lebih sering dilakukan oleh perusahaan. Dividen merupakan pendapatan yang sudah pasti diterima sedangkan capital gain merupakan pendapatan yang belum pasti karena masih berupa ekspektasi para pemegang saham. Selain itu, capital gain dianggap lebih berisiko dibandingkan dengan dividen karena adanya kemungkinan harga saham yang dijual tidak sesuai dengan yang diharapkan oleh pemegang saham. Ketidakpastian yang diperoleh pemegang saham dapat berkurang jika perusahaan melakukan pembagian dividen. Pemegang saham tentunya lebih menyukai pembagian dividen yang cenderung stabil bahkan meningkat dari periode sekarang ke periode selanjutnya. Pembagian dividen yang stabil diharapkan dapat meningkatkan kepercayaan pemegang saham dalam mengambil keputusan investasi.

Kebijakan dividen memerlukan peran manajemen perusahaan. Manajemen selaku pengelola perusahaan tidak hanya berfungsi untuk meningkatkan nilai perusahaan tetapi juga mampu meningkatkan kemakmuran bagi para pemegang sahamnya. Manajer diharapkan dapat menghasilkan keuntungan yang akhirnya dapat dibagikan kepada pemegang saham dalam bentuk dividen serta mempertimbangkan keputusan investasi dan keputusan pendanaan yang tepat untuk perusahaan. Oleh karena itu, manajemen perlu membuat kebijakan dividen yang optimal untuk menciptakan keseimbangan antara dividen saat ini dan pertumbuhan di masa yang akan datang sehingga dapat memaksimalkan harga saham (Brennan dan Thakor, 1990 dalam (Paramita, 2015). Penetapan pembagian dividen ini menjadi masalah yang menarik karena di satu sisi dividen digunakan untuk memenuhi keinginan pemegang saham, tetapi di sisi lain kebijakan tersebut diharapkan tidak menghambat kelangsungan hidup perusahaan.

Masalah agensi dianggap sebagai salah satu masalah utama antara pemegang saham dengan pihak manajemen. Para pemegang saham biasanya menyerahkan kepada manajer untuk mengurus perusahaan. Manajer belum tentu bertindak sesuai dengan keinginan pemegang saham. Kondisi ini yang akan memicu konflik antara pemegang saham dan manajer perusahaan. Pemegang saham memberikan hak kepada manajer untuk melaksanakan tugas dalam mengatur keuangan perusahaan, akibatnya manajer lebih mengetahui informasi keuangan dibandingkan pemegang saham (Roring \& Roni, 2014). Untuk mencegah para manajer bertindak dengan tujuan pribadi, maka perlu dilakukan suatu mekanisme pengawasan (Roring \& Roni, 2014). Mekanisme pengawasan memerlukan biaya dalam perusahaan yang dikenal dengan biaya agensi(Roring \& Roni, 2014). Salah satu cara untuk mengurangi biaya agensi adalah dengan melakukan pembagian dividen (Crutchley \& Hansen, 1989).

Ross (1977) berpendapat bahwa manajer yang bertindak sebagai pengelola perusahaan memiliki kewajiban untuk memberikan sinyal mengenai kondisi perusahaan kepada pemegang saham. Salah satu bentuk sinyal yang diberikan yaitu dengan melakukan pengumuman dividen. Pengumuman dividen dianggap memiliki kandungan informasi apabila pasar bereaksi pada saat pengumuman tersebut diterima oleh pasar (Embara, Putu W, \& Badjra, 2012). Pemegang saham akan menginterpretasikan peningkatan pembayaran dividen oleh perusahaan sebagai sinyal bahwa pihak manajemen memiliki prediksi arus kas yang tinggi di masa yang akan datang sedangkan penurunan pembayaran dividen diinterpretasikan sebagai antisipasi manajer terhadap terbatasnya arus kas di masa yang akan datang (Black, 1976)

Perusahaan property dan real estate merupakan salah satu alternatif investasi yang diminati investor karena investasi di sektor ini merupakan investasi jangka panjang dan properti merupakan aktiva multiguna yang dapat digunakan oleh perusahaan sebagai jaminan, sehingga perusahaan property dan real estate memiliki struktur modal yang tinggi. Harga tanah yang cenderung naik dari tahun ke tahun dikarenakan jumlah tanah yang terbatas sedangkan permintaan yang terus meningkat seiring dengan peningkatan jumlah penduduk serta penentu harga bukanlah pasar melainkan pihak (orang) yang menguasai tanah tersebut membuat industri property dan real estate ini semakin disukai oleh investor karena berinvestasi di sektor ini dianggap menguntungkan.

Tabel 1 Rata-Rata Dividend payout ratio, Free cash flow, Kepemilikan Institusional,

Profitabilitas dan Leverage Perusahaan Property dan Real estate

\begin{tabular}{ccccccc}
\hline Variabel & $\mathbf{2 0 1 4}$ & $\mathbf{2 0 1 5}$ & $\mathbf{2 0 1 6}$ & $\mathbf{2 0 1 7}$ & $\mathbf{2 0 1 8}$ & $\mathbf{2 0 1 9}$ \\
\hline D & 0,24 & 0,44 & 0,35 & 0,43 & 0,33 & 0,27 \\
X1 & 0,10 & 0,14 & 0,10 & 0,09 & 0,09 & 0,08 \\
X2 & 0,55 & 0,56 & 0,57 & 0,57 & 0,57 & 0,58 \\
X3 & 0,08 & 0,08 & 0,09 & 0,07 & 0,07 & 0,08 \\
X4 & 0,64 & 0,67 & 0,75 & 0,90 & 1,00 & 1,05 \\
\hline
\end{tabular}

Sumber: www.idx.co.id (data diolah kembali)

Berdasarkan tabel 1 diatas dapat diketahui bahwa rata-rata Dividend payout ratio perusahaan property dan real estate yang rutin membagikan dividennya sepanjang tahun 2014 sampai dengan tahun 2017 berfluktuasi dan kemudian mengalami penurunan sampai dengan tahun 2019. Variabel free cash flow sepanjang periode penelitian memiliki rata-rata yang berfluktuatif. Jika rata-rata free cash flow dibandingkan dengan rata-rata Dividend payout ratio, dapat terlihat bahwa kenaikan Dividend payout ratio tidak selalu diiringi dengan kenaikan free cash flow. Begitu pula dengan variabel kepemilikan 
institusional yang semakin meningkat selama periode penelitian. Namun jika rata-rata kepemilikan institusional dibandingkan dengan rata-rata Dividend payout ratio, dapat terlihat bahwa peningkatan kepemilikan institusional ini juga tidak selalu diiringi dengan peningkatan Dividend payout ratio.

Selain itu, variabel profitabilitas yang diproksikan dengan Return on Assets juga memiliki rata-rata yang berfluktuatif selama periode penelitian Jika rata-rata Return on Assets dibandingkan dengan rata-rata Dividend payout ratio, dapat terlihat bahwa kenaikan Dividend payout ratio tidak selalu diiringi dengan kenaikan return on assets. Sementara itu, variabel Leverage yang diproksikan dengan debt to equity ratio terus mengalami peningkatan selama periode penelitian. Akan tetapi, jika rata-rata debt to equity ratio dibandingkan dengan rata- rata Dividend payout ratio dapat terlihat bahwa peningkatan debt to equity ratio tidak selalu diikuti dengan penurunan Dividend payout ratio.

Free cash flow atau aliran kas bebas adalah kas yang tersisa setelah melakukan seluruh proyek yang menghasilkan net present value positif saat didiskontokan dengan biaya modal yang relevan (Michael C Jensen, 1986). Pada saat perusahaan memiliki free cash flow, manajer mendapatkan tekanan dari para pemegang saham untuk membagikan dividen (Pujiastuti, 2008). Padahal manajer lebih menginginkan dana tersebut untuk diinvestasikan kembali pada proyek-proyek yang dapat menghasilkan keuntungan (Pujiastuti, 2008). Free cash flow sebaiknya dibagikan sebagai dividen atau digunakan untuk membayar hutang sehingga dapat menghindari kemungkinan para manajer melakukan investasi yang merugikan (investasi pada net present value negatif) (Michael C Jensen, 1986). Bila perusahaan memiliki free cash flow yang tinggi dan tingkat pertumbuhan yang rendah maka free cash flow ini seharusnya didistribusikan kepada pemegang saham, tetapi jika perusahaan memiliki tingkat pertumbuhan yang tinggi maka free cash flow ini akan ditahan sementara dan dimanfaatkan untuk investasi pada periode mendatang (Rosdini, 2009).

Thanatawee (2013) menyatakan bahwa kepemilikan institusional dapat mempengaruhi kebijakan dividen di suatu perusahaan. Hal ini dikarenakan kepemilikan institusional dianggap lebih mampu melakukan pengawasan terhadap manajemen perusahaan daripada kepemilikan yang menyebar dan kecil (Allen \& Michaely, 2001). Peningkatan pengawasan yang dilakukan oleh pemegang saham institusional diharapkan dapat membuat manajer bertindak dengan lebih optimal sehingga dapat mengurangi perilaku oportunistik dari manajer. Untuk menunjukan bahwa manajer telah bekerja secara optimal, maka manajer dapat menggunakan pembayaran dividen untuk mengkomunikasikan informasi mengenai pendapatan perusahaan secara umum. Pembayaran dividen inilah dianggap sebagai bentuk sinyal dari manajer kepada pemegang saham institusi bahwa perusahaan memiliki kinerja yang baik, sehingga pemegang saham institusi percaya bahwa modal yang telah mereka tanamkan di perusahaan tersebut telah dikelola dengan baik oleh manajer. Bagi perusahaan yang kinerjanya tidak begitu baik akan sulit dalam mengambil keputusan untuk membagikan dividen.

\section{METODE}

\section{Populasi dan Sampel}

Popula Populasi dalam penelitian ini adalah seluruh perusahaan property dan real estate yang terdaftar di Bursa Efek Indonesia pada tahun 2014-2019. Sementara itu, sampel dipilih dengan metode purposive sampling.

Adapun kriteria yang digunakan dalam penelitian ini adalah sebagai berikut:

1. Perusahaan property dan real estate yang terdaftar di Bursa Efek Indonesia pada tahun 2014-2019.

2. Perusahaan yang membagikan dividen pada tahun 2014-2019.

3. Perusahaan yang memiliki free cash flow positif pada tahun 2014-2019

\section{Jenis dan Sumber Data}

Jenis data yang digunakan dalam penelitian ini adalah data kuantitatif. Adapun sumber data yang digunakan dalam penelitian ini merupakan data sekunder yang berasal laporan keuangan tahunan perusahaan yang telah diaudit untuk tahun buku yang berakhir pada tanggal 31 Desember 2014 sampai dengan 31 Desember 2019. Semua sumber data yang digunakan untuk menghitung tiap-tiap faktor dalam penelitian ini diperoleh dari website www.idx.co.id.

\section{Definisi Operasional dan Pengukuran Variabel}

\section{Variabel Dependen}

Kebijakan dividen tunai diukur dengan menggunakan Dividend payout ratio. Dividend payout ratio adalah rasio perbandingan antara laba yang dibagikan perusahaan kepada pemegang saham dalam bentuk dividen per lembar saham dibagi laba per lembar saham. Adapun kebijakan dividen tunai dihitung dengan rumus yang bersumber dari (Horne \& Wachowicz, 2007) yaitu:

$$
D=\frac{D L S}{L L S}
$$


Dengan

$\mathrm{D}=$ Dividend payout ratio

DLS $=$ Dividen per lembar saham

LLS = Laba per lembar saham

Variabel Independen

1. Free cash flow

Free cash flow atau arus kas bebas adalah kas yang tersedia di perusahaan setelah digunakan untuk membiayai investasi yang menghasilkan net present value positif. Adapun free cash flow dihitung dengan rumus yang bersumber dari penelitian (Suhartono, 2015) yaitu:

$$
X_{1}=\frac{K B-D}{T A}
$$

Dengan

$\mathrm{X} 1=$ Free cash flow

$\mathrm{KB}=$ kas bersih dari aktivitas Operasi

$\mathrm{D}=$ Dividen

$\mathrm{TA}=$ Total Aset

2. Kepemilikan Institusional

Kepemilikan Institusional adalah jumlah saham yang dimiliki oleh institusi atau lembaga eksternal perusahaan baik institusi dalam negeri maupun luar negeri. Adapun kepemilikan institusional dihitung dengan rumus yang bersumber dari penelitian (Sari \& Budiasih, 2016) yaitu:

$$
X_{2}=\frac{J S I}{J S B}
$$

$$
\begin{aligned}
& \text { Dengan } \\
& \text { X2= Kepemilikan Institusional } \\
& \text { JSI = Jumlah saham yang dimiliki Institusi } \\
& \text { JSB = Jumlah Saham yang beredar }
\end{aligned}
$$

3. Profitabilitas

Profitabilitas adalah kemampuan perusahaan dalam menghasilkan laba dari aktivitas normal bisnisnya (Hery, 2016). Profitabilitas diukur dengan Return on Assets (ROA) untuk menunjukan seberapa besar kontribusi aset dalam menciptakan laba bersih. Adapun profitabilitas dihitung dengan rumus yang bersumber dari (Hery, 2016) yaitu

$$
X_{3}=\frac{L B}{T A}
$$

$$
\begin{aligned}
& \text { Dengan } \\
& \mathrm{X} 3=\text { Return on Assets (profitabilitas) } \\
& \mathrm{LB}=\text { Laba bersih } \\
& \mathrm{TA}=\text { Total aset }
\end{aligned}
$$

\section{Leverage}

Leverage merupakan kemampuan perusahaan dalam memenuhi kewajiban jangka pendek maupun kewajiban jangka panjang (Hery, 2016). Leverage diukur dengan Debt to equity ratio untuk mengukur seberapa besar proporsi kewajiban terhadap ekuitas. Adapun Leverage dihitung dengan rumus yang bersumber dari (Hery, 2016) yaitu 


$$
X_{4}=\frac{T K}{T E}
$$

$$
\begin{aligned}
& \text { Dengan } \\
& \mathrm{X} 4=\text { Debt to equality ratio } \\
& \mathrm{TK}=\text { Total kewajuban } \\
& \mathrm{TE}=\text { Total Ekuitas }
\end{aligned}
$$

5. Uji Regresi Linear Berganda

Alat analisis yang digunakan untuk hipotesis adalah analisis regresi linear berganda. Persamaan yang digunakan untuk menguji hubungan hipotesis adalah sebagai berikut:

$$
Y=a+b_{1} X_{1}+b_{2} X_{2}+b_{3} X_{3}+b_{4} X_{4}+e
$$

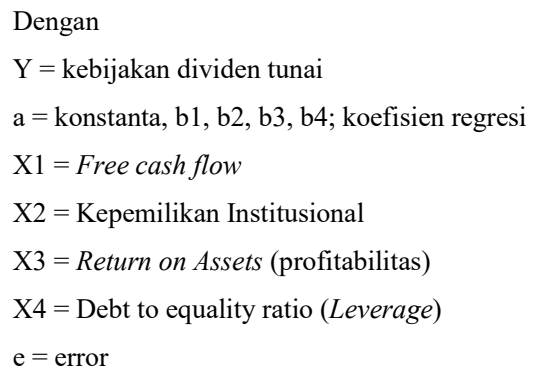

\section{HASIL DAN PEMBAHASAN}

\section{Hasil Seleksi Sampel}

Berdasarkan Berdasarkan proses pemilihan sampel dengan menggunakan purposive sampling, maka diperoleh jumlah perusahaan yang memenuhi kriteria sebanyak 5 perusahaan dengan jumlah sampel yang diteliti sebanyak 30 data.

\section{Hasil Analisis Statistik Deskriptif}

Tabel 2 Statistik Deskriptif

\begin{tabular}{cccccc}
\hline Variabel & N & Min & Max & Mean & $\begin{array}{c}\text { Std. } \\
\text { Deviation }\end{array}$ \\
\hline D & 30 & 0,0171 & 1,0000 & 0,3444 & 0,2457 \\
X1 & 30 & 0,0055 & 0,2434 & 0,0986 & 0,0706 \\
X2 & 30 & 0,0732 & 0,8946 & 0,5648 & 0,2754 \\
X3 & 30 & 0,0081 & 0,1558 & 0,0759 & 0,0399 \\
X4 & 30 & 0,2863 & 1,8338 & 0,8354 & 0,4224 \\
\hline
\end{tabular}

Berdasarkan tabel 2 diatas, maka dapat diketahui nilai rata-rata kebijakan dividen tunai yang diproksikan dengan DPR yaitu sebesar 0,3444 dengan standar deviasi sebesar 0,2457. Nilai minimum sebesar 0,0171 dimiliki oleh PT. Plaza Indonesia Reality Tbk tahun 2014 sedangkan nilai maksimum sebesar 1 dimiliki oleh PT. Plaza Indonesia Reality Tbk di tahun 2015 dan tahun 2017.

Variabel free cash flow memiliki nilai rata- rata sebesar 0,0986 dengan standar deviasi sebesar 0,0706. Nilai minimum sebesar 0,0055 dimiliki oleh PT Pudjiadi Prestige Tbk tahun 2019 sedangkan nilai maksimum sebesar 0,2434 dimiliki oleh PT Metropolitan Kentjana Tbk tahun 2018. Variabel kepemilikan institusional memiliki nilai rata-rata sebesar 0,5648 dengan standar deviasi sebesar 0,2754. Nilai minimum sebesar 0,0732 dimiliki oleh PT Ciputra Development Tbk tahun 2016 sedangkan nilai maksimum sebesar 0,8946 dimiliki oleh PT Plaza Indonesia Realty Tbk tahun 2018. 
Variabel profitabilitas yang diproksikan dengan X3 memiliki nila rata-rata sebesar 0,0759 dengan standar devasi 0,0399. Nilai minimum sebesar 0,0081 dimiliki oleh PT Plaza Indonesia Realty Tbk tahun 2017 dan nilai maksimum sebesar 0,1558 dimiliki oleh PT Metropolitan Kentjana Tbk tahun 2019. Variabel Leverage yang diproksikan dengan X4 memiliki nilai rata-rata sebesar 0,8354 dengan standar deviasi sebesar 0,4224. Nilai minimum sebesar 0,2863 dimiliki oleh PT Pudjiadi Prestige Tbk tahun 2014 sedangkan nilai maksimum sebesar 1,8338 dimiliki oleh PT Alam Sutera Realty Tbk tahun 2019.

\section{Analisa regresi Linear Berganda}

Tabel 3 Hasil Uji Regresi Linear berganda

\begin{tabular}{cccc}
\hline Model & \multicolumn{2}{c}{$\begin{array}{c}\text { Unstandardized } \\
\text { Coefficient }\end{array}$} & $\begin{array}{c}\text { Standardized } \\
\text { Coefficient }\end{array}$ \\
\cline { 2 - 3 } & B & Std. error & Beta \\
\hline (constant) & 0,268 & 0,122 & \\
X1 & 1,552 & 0,638 & 0,446 \\
X2 & 0,488 & 0,137 & 0,546 \\
X3 & $-3,678$ & 1,115 & $-0,597$ \\
X4 & $-0,088$ & 0,085 & $-0,151$ \\
\hline
\end{tabular}

Berdasarkan tabel 3 diatas maka dapat diperoleh persamaan regresi dalam penelitian ini yaitu sebagai berikut:

$\mathrm{Y}=\mathbf{0 , 2 6 8}+1,552 \mathrm{X} 1+\mathbf{0 , 4 8 8} \mathrm{X} 2-3,678 \times 3-0,088 \mathrm{X} 4+\mathrm{e}$

Tabel 4. Hasil Uji t (Uji Parsial)

\begin{tabular}{ccc}
\hline Model & $\mathbf{t}$ & Sig. \\
\hline (constant) & 2,201 & 0,037 \\
X1 & 2,434 & 0,022 \\
X2 & 3,572 & 0,001 \\
X3 & $-3,298$ & 0,003 \\
X4 & $-1,028$ & 0,314 \\
\hline
\end{tabular}

Berdasarkan tabel 4 diatas maka dapat terlihat bahwa variabel free cash flow (X1), kepemilikan institusional dan profitabilitas memiliki pengaruh yang signifikan terhadap Dividend payout ratio sedangkan Leverage (X4) tidak memiliki pengaruh yang signifikan terhadap Dividend payout ratio.

\section{Pengaruh Free cash flow Terhadap Kebijakan Dividen Tunai}

Hasil penelitian ini menunjukan bahwa free cash flow berpengaruh positif dan signifikan terhadap kebijakan dividen tunai. Hal ini dibuktikan dengan hasil uji statistik yang menunjukan nilai thitung sebesar 2,434 dengan tingkat signifikansi 0,022 yang berarti lebih kecil dari 0,05. Hasil penelitian ini sejalan dengan penelitian yang dilakukan oleh (Rosdini, 2009), (Embara et al., 2012), (Suhartono, 2015), (Paramita, 2015), serta (Sari \& Budiasih, 2016) yang menyatakan bahwa free cash flow berpengaruh positif dan signifikan terhadap kebijakan dividen. Arah positif dalam penelitian ini memberikan arti bahwa semakin tinggi free cash flow maka pihak manajemen perusahaan akan meningkatkan pembayaran dividennya untuk diberikan kepada pemegang saham atau ketika free cash flow perusahaan mengalami penurunan maka pihak manajemen perusahaan akan menurunkan pembayaran dividennya.

Arus kas bebas (free cash flow) merupakan jumlah arus kas yang tersedia bagi investor setelah perusahaan memenuhi seluruh kebutuhan operasi dan mengkover dana untuk investasi (Hadianto \& Herlina, 2010). Ketika perusahaan menghasilkan arus kas bebas dalam jumlah yang sangat besar terjadi konflik kepentingan antara pemegang saham dan manajer (Michael C Jensen, 1986). Pemegang saham menginginkan sisa dana tersebut dibagikan sebagai dividen untuk meningkatkan kesejahteraannya, sementara itu pihak manajer berkeinginan menggunakan dana tersebut untuk diinvestasikan kembali pada proyek-proyek yang menguntungkan karena akan menambah insentif yang diterima(Arilaha, 2009).

Berdasarkan free cash flow hypothesis, konflik agensi yang terjadi antara manajer dengan pemegang saham akibat adanya kecenderungan manajer untuk berperilaku oportunistik dengan menggunakan kelebihan aliran kas untuk meningkatkan kekuasaanya melalui investasi yang berlebihan atau pengeluaran yang tidak berkaitan dengan kegiatan perusahaan. Untuk mengatasi konflik atas kendali kas bebas tersebut maka pihak manajemen perusahaan sebaiknya membagikan kepada pemegang saham melalui pembayaran dividen sehingga kendali atas arus kas bebas tidak lagi berada di tangan manajer namun sudah berpindah ke tangan pemegang saham dalam bentuk dividen untuk meningkatkan kemakmuran pemegang saham. 
Megginson (1997) dalam (Embara et al., 2012) menyatakan bahwa aliran kas bebas yang dihasilkan perusahaan akan memiliki dampak berupa peningkatan pembayaran dividen. Penyataan tersebut juga didukung oleh (Allen \& Michaely, 2001) yang menyatakan bahwa penurunan dalam kesempatan investasi akan menghasilkan peningkatan dalam aliran kas bebas, dimana adanya peningkatan aliran kas bebas ini akan mendorong pada peningkatan pembayaran dividen, namun pihak manajemen akan melakukan penurunan pembayaran dividen bila aliran kas bebas yang dimiliki perusahaan menurun.

\section{Pengaruh kepemimpinan Instusional Terhadap kebijakan Dividen Tunai}

Hasil penelitian ini menunjukan bahwa kepemilikan institusional berpengaruh positif dan signifikan terhadap kebijakan dividen tunai. Hal ini dibuktikan dengan hasil uji statistik yang menunjukan nilai t hitung sebesar 3,572 dengan tingkat signifikansi 0,001 yang berarti lebih kecil dari 0,05 . Hasil penelitian ini sejalan dengan penelitian yang dilakukan oleh (Embara et al., 2012), (Thanatawee, 2013), (Suhartono, 2015) yang menyatakan bahwa kepemilikan institusional berpengaruh positif dan signifikan terhadap kebijakan dividen. Arah positif dalam penelitian ini memberikan arti bahwa semakin tinggi kepemilikan institusional maka pihak manajemen perusahaan akan meningkatkan pembayaran dividennya atau semakin rendah kepemilikan institusional maka pihak manajemen perusahaan akan menurunkan pembayaran dividennya. Hal ini dikarenakan pemegang saham institusi memiliki informasi yang lebih baik dari pemegang saham perorangan dan memiliki kemampuan pengawasan yang lebih baik sehingga kepemilikan institusi berpengaruh positif terhadap kebijakan dividen (Grinstein dan Michaely, 2003 dalam (Embara et al., 2012).

Berdasarkan teori agensi yang dikemukakan oleh (M. C Jensen \& Meckling, 1976) adanya pemisahan fungsi kepemilikan dan pengelolaan perusahaan antara pemegang saham dan manajer menyebabkan adanya konflik kepentingan. Salah satu cara yang dapat ditempuh untuk mengurangi konflik tersebut yaitu dengan meningkatkan kepemilikan institusional. Keberadaan pemegang saham institusional ini diharapkan mampu melaksanakan fungsi monitoring atau pengawasan yang efektif terhadap kinerja manajemen perusahaan karena kepemilikan saham mewakili sumber kekuasaan pemegang saham yang dapat digunakan untuk mengendalikan pihak manajemen perusahaan. Fungsi monitoring atau pengawasan ini bertujuan agar manajemen bertindak sesuai dengan tujuan pemegang saham yaitu dengan mementingkan kemakmuran pemegang saham dan bukan mengutamakan kepentingan pribadi atau berperilaku oportunistik. Kepemilikan institusional yang tinggi mampu mendorong manajemen perusahaan untuk bertindak selaras dengan kepentingan pemegang saham yakni melalui pembagian dividen. Selain itu, pembayaran dividen dapat dikatakan efektif sebagai insentif dari upaya monitoring yang telah dilaksanakan pemegang saham institusional terhadap manajemen perusahaan.

\section{Pengaruh Profitabilitas Terhadap Kebijakan Dividen Tunai}

Hasil penelitian ini menunjukan bahwa profitabilitas berpengaruh negatif dan signifikan terhadap kebijakan dividen tunai. Hal ini dibuktikan dengan hasil uji statistik yang menunjukan nilai t hitung sebesar -3,298 dengan tingkat signifikansi 0,003 yang berarti lebih kecil dari 0,05. Berdasarkan teori sinyal, perusahaan akan membagikan jumlah dividen yang tinggi untuk memberikan sinyal kepada investor bahwa pihak manajemen perusahaan memandang prospek yang baik di masa mendatang. Namun, hasil penelitian ini menunjukan bahwa semakin tinggi profitabilitas suatu perusahaan yang diukur melalui ROA maka pihak manajemen perusahaan cenderung melakukan penurunan pembayaran dividennya. Hal ini membuktikan bahwa hasil dari penelitian ini tidak sejalan dengan penelitian yang dilakukan oleh (Suharli, 2006), (Arilaha, 2009) dan (Paramita, 2015), tetapi sejalan dengan penelitian yang dilakukan oleh (Septian \& Lestari, 2016). Dikemukakan bahwa perusahaan yang mengalami peningkatan profitabilitas justru akan menurunkan pembayaran dividennya karena perusahaan akan menggunakan laba yang diperoleh tersebut untuk kegiatan operasi perusahaan atau untuk berinvestasi sehingga akan mengurangi pembayaran dividen.

Pernyataan tersebut didukung oleh pendapat (Graham, 2016) yang mengemukakan bahwa pihak manajemen perusahaan lebih suka menahan laba untuk memperkuat perusahaan. Semakin baik catatan pertumbuhan perusahaan di masa lalu maka investor harus siap menerima kebijakan dividen rendah (Graham, 2016). Perusahaan yang kuat dan berkembang lebih cenderung menekan jumlah pembayaran dividennya (Graham, 2016). Hal ini dikarenakan perusahaan akan menggunakan laba tersebut untuk ekspansi sehingga pihak manajemen mengorbankan kepentingan pemegang saham saat ini demi kelangsungan hidup perusahaan dan keuntungan jangka panjang para investor (Graham, 2016).

Selain itu salah satu syarat pembagian dividen adalah tersedianya cukup kas. Dalam akuntasi, penyusunan laporan laba rugi diukur atas dasar akrual (accrual basis) dimana biaya yang telah terjadi ditandingkan dengan pendapatan dalam periode yang sama (matching concept). Dengan demikian, saldo yang tertera dalam laba bersih tidak identik dengan jumlah kas yang tersedia. Oleh karena itu meskipun perusahaan memiliki rasio profitabilitas 
yang tinggi belum tentu akan turut meningkatkan rasio pembayaran dividennya. Hal ini dikarenakan tidak adanya keterkaitan (hubungan) antara saldo kas dengan laba bersih. Oleh sebab itu sebelum mengumumkan dividen tunai, dewan direksi melalui jajaran direksinya (direktur keuangan) akan mengevaluasi terlebih dahulu besarnya posisi kas yang tersedia dan jumlah estimasi kebutuhan kas jangka pendek, setelah uang kas yang tersedia dirasa cukup untuk membayar dividen tunai kemudian dewan direksi akan melakukan pengumuman dividen (Hery, 2016).

\section{Pengaruh Leverage Terhadap Kebijakan Dividen Tunai}

Hasil penelitian ini menunjukan bahwa Leverage tidak berpengaruh signifikan terhadap kebijakan dividen tunai. Hal ini dibuktikan dengan hasil uji statistik yang menunjukan nilai t hitung sebesar -1,028 dengan tingkat signifikansi 0,314 yang berarti lebih besar dari 0,05. Hasil penelitian ini tidak sejalan dengan penelitian yang dilakukan oleh (Pujiastuti, 2008) dan (Puspitasari, 2014) tetapi sejalan dengan penelitian yang dilakukan oleh (Arilaha, 2009) dan (Puteri, Budi K, \& Nugroho, 2012) yang menyatakan bahwa Leverage tidak berpengaruh signifikan terhadap kebijakan dividen.Dalam membiayai investasinya, perusahaan memerlukan modal yang dapat berasal dari utang maupun ekuitas. Leverage dalam penelitian ini diproksikan dengan debt to equity ratio yang menggambarkan seberapa besar kemampuan ekuitas atas kewajiban perusahaan. Semakin besar rasio ini menandakan bahwa semakin tinggi beban yang ditanggung perusahaan. Hal ini dapat dijelaskan bahwa dengan proporsi utang yang semakin besar maka perusahaan memiliki kewajiban terhadap pihak ekstenal (kreditur) berupa beban bunga dan pokok utang yang besar, sehingga keuntungan yang dapat dibagikan kepada pemilik saham menjadi menurun.

Namun, hasil penelitian ini menunjukan bahwa Leverage tidak memiliki pengaruh yang signifikan terhadap kebijakan dividen tunai. Meskipun tidak memiliki pengaruh yang signifikan, Leverage memiliki nilai t negatif yang berarti variabel ini memiliki arah negatif. Perusahaan yang memiliki struktur permodalan yang terdiri dari kreditur dan pemegang saham menyebabkan pihak manajemen tidak hanya memperhatikan kepentingan kreditur berupa pelunasan kewajiban saja tetapi juga memperhatikan kepentingan pemegang saham dengan membagikan dividen. Jika dilihat rata- rata Dividend payout ratio dan rata-rata debt to equity ratio perusahaan property dan real estate yang rutin membagikan dividen dapat diketahui bahwa kemampuan pembayaran dividen tidak selalu bergantung pada besar atau kecilnya utang yang dimiliki oleh perusahaan, bahkan perusahaan yang mengalami peningkatan utang tetap meningkatkan pembayaran dividennya sehingga hal ini menyebabkan pengaruh Leverage yang diproksikan dengan debt to equity ratio terhadap kebijakan dividen tunai menjadi tidak signifikan.

\section{KESIMPULAN}

Berdasarkan hasil penelitian mengenai pengaruh free cash flow, kepemilikan institusional, profitabilitas dan leverage pada perusahaan property dan real estate yang terdaftar di Bursa Efek Indonesia, maka dapat ditarik kesimpulan sebagai berikut:

1. Free cash flow berpengaruh positif dan signifikan terhadap kebijakan dividen tunai yang diukur menggunakan Dividend payout ratio. Hasil ini dapat menjelaskan bahwa semakin tinggi free cash flow maka pihak manajemen akan meningkatkan pembayaran dividennya karena menurut free cash flow hypothesis adanya kecenderungan manajer untuk berperilaku oportunistik dengan menggunakan free cash flow pada investasi yang tidak menguntungkan perusahaan sehingga pembayaran dividen yang tinggi dapat digunakan untuk mengurangi terjadinya konflik agensi dan perilaku oportunistik manajer.

2. Kepemilikan institusional berpengaruh positif dan signifikan terhadap kebijakan dividen tunai yang diukur menggunakan Dividend payout ratio. Hasil ini dapat menjelaskan bahwa semakin tinggi kepemilikan institusional maka semakin tinggi dividen yang dibayarkan karena menurut teori agensi adanya pemisahan fungsi kepemilikan dan pengelolaan antara manajer dan pemegang saham menyebababkan manajer tidak selalu bertindak sesuai dengan kepentingan terbaik pemegang saham. Peningkatan kepemilikan institusional dianggap sebagai salah satu cara untuk mengurangi konflik agensi karena pemegang saham institusi dianggap sebagai pihak profesional yang lebih mampu melakukan pengawasan serta dapat mempengaruhi keputusan strategis perusahaan.

3. Profitabilitas berpengaruh negatif dan signifikan terhadap kebijakan dividen tunai yang diukur menggunakan Dividend payout ratio. Hasil ini dapat menjelaskan bahwa semakin tinggi profitabilitas perusahaan maka semakin rendah dividen yang dibayarkan karena ketika perusahaan memiliki tingkat profitabilitas yang tinggi maka pihak manajemen perusahaan cenderung akan menahan laba bersihnya lebih besar dibandingkan membayar dividen yang tinggi untuk kegiatan reinvestasi perusahaan. 
4. Leverage tidak berpengaruh signifikan terhadap kebijakan dividen tunai yang diukur menggunakan Dividend payout ratio. Hasil ini dapat menjelaskan bahwa perusahaan yang memiliki leverage yang tinggi tidak selalu menurunkan pembayaran dividennya. Hal ini dikarenakan pihak manajemen perusahaan tetap memperhatikan kemakmuran pemegang saham meskipun perusahaan juga memiliki kewajiban terhadap kreditur.

5.

\section{DAFTAR PUSTAKA}

Allen, F., \& Michaely, R. (2001). Payout Policy. Working Paper. Cornell Univesity.

Arilaha, M. A. (2009). Pengaruh Free cash flow, Profitabilitas, Likuiditas dan Leverage Terhadap Kebijakan Dividen. Jurnal Keuangan Dan Perbankan, 13(1), 78-87.

Black, F. (1976). The Dividend Puzzle. Journal Of Portfolio Management, 2(winter), 8-12.

Crutchley, C. E., \& Hansen. (1989). A Test of The Agency Theory of Managerial Ownership, Corporate Leverage and Corporate Dividens. Financial Management, 18, 36-39.

Embara, C. T. D. L., Putu W, N. L., \& Badjra, I. A. (2012). Variabel-Variabel yang Berpengaruh Terhadap Kebijakan Dividen Serta Harga Saham Pada Perusahaan Manufaktur di Bursa Efek Indonesia. Jurnal Manajemen, Strategi Bisnis, Dan Kewirausahaan, 6(2), 119-129.

Graham, B. (2016). The Intelligent Investor: Ajaran-Ajaran Inti Dalam Berinvestasi. Jakarta: CV Pijar Nalar Indonesia.

Hadianto, B., \& Herlina. (2010). Prediksi Arus Kas Bebas, Kebijakan Utang dan Profitabilitas Terhadap Kemungkinan Dibayarkannya Dividen (Studi Empirik Pada Emiten Pembentuk Indeks Kompas 100 di Bursa Efek Indonesia). Jurnal Manajemen Bisnis, 3(1), 53-74.

Hery. (2016). Analisis Laporan Keuangan Integrated and Comprehensive Edition. Jakarta: PT Grasindo.

Horne, J. C. V, \& Wachowicz, J. M. (2007). Fundamentals of Financial Management: Prinsip-Prinsip Manajemen Keuangan 2. Jakarta: Salemba Empat. Jensen, M. C. (1986). Agency Cost of Free cash flow, Corporate Finance, and Takeovers. The American Economic Review, 76(2), 323-329.

Jensen, M. C., \& Meckling, W. H. (1976). Theory of the firm: Managerial Behavior, Agency Cost dan Ownership Structure. Journal of Financial Economics, 3(4), 305-360.

Paramita, R. A. (2015). Free cash flow, Leverage, Besaran dan Siklus Hidup Perusahaan: Bukti Kebijakan Dividen di Indonesia. Jurnal Riset Ekonomi Dan Manajemen, 15(1), 169-181.

Pujiastuti, T. (2008). Agency Cost terhadap Kebijakan Dividen pada Perusahaan Manufaktur dan Jasa yang Go Public di Indonesia. Jurnal Keuangan Dan Perbankan, 12(2), 183-197.

Puspitasari, N. A. (2014). Faktor-Faktor yang Berpengaruh Terhadap Kebijakan Dividen. Universitas Diponegoro.

Puteri, F. C., Budi K, A., \& Nugroho, P. I. (2012). Analisis Faktor-Faktor yang Mempengaruhi Kebijakan Dividen. Proceedings of Conference In Business, Accounting and Management, 1(1), 269-282.

Roring, R., \& Roni, S. (2014). Pengaruh Biaya Agensi dan Siklus Hidup Perusahaan Terhadap Kebijakan Dividen Pada Industri Manufaktur. FINESTA, 2(2), 63-67.

Rosdini, D. (2009). Pengaruh Free cash flow Terhadap Dividend payout ratio (Working Pa). Universitas Padjajaran.

Ross, S. A. (1977). The Determination of Financial Structure: The Incentive-Signalling Approach. Bell Journal of Economics, 8(1), $23-40$.

Sari, N. K. A., \& Budiasih, I. G. A. (2016). Pengaruh Kepemilikan Managerial, Kepemilikan Institusional, Free cash flow dan Profitabilitas Pada Kebijakan Dividen. E- Jurnal Akuntansi Universitas Udayana, 15(3), 2439-2465.

Septian, R., \& Lestari, H. S. (2016). Faktor-Faktor yang Mempengaruhi Dividend Policy Pada Perusahaan Non- Financial yang Terdaftar di Bursa Efek Indonesia. Seminar Nasional Cendekiawan 2, 30(13), 1-30.

Suharli, M. (2006). Studi Empiris Mengenai Pengaruh Profitabilitas, Leverage, dan Harga Saham Terhadap Jumlah Dividen Tunai (Studi pada Perusahaan yang Terdaftar di Bursa Efek Jakarta Periode 2002-2003). Jurnal Maksi, 6(2), 243-256.

Suhartono, A. (2015). The Effect of Free cash flow and Ownership Structure on Dividend payout ratio in Manufacturing Companies in Indonesia. Indonesian Accounting Review, 5(2), 129-140.

Thanatawee, Y. (2013). Ownership Structure and Dividend Policy: Evidence from Thailand. International Journal of Economics and Finance, 5(1), 121132. 